a todos los que hicieron posible que este libro saliera a la luz, el cual, ni duda cabe, está Ilamado a convertirse en la referencia obligada de estudio y consulta para todos aquellos que quieran o necesiten acercarse al rico acervo que guarda la BUAp, la calidad de cuyas obras puede ser heterogénea, pero no por ello es un conjunto indigno de nuestra atención. Y si es cierto aquello de que sólo se ama lo que se conoce, este libro es el vehículo ideal para que todos, estudiosos y público en general, tengamos la posibilidad de conocer y entrar en contacto con las piezas más selectas de esta rica colección. La custodia, el estudio y la difusión de la misma son tareas que deben significar una enorme responsabilidad para la Benemérita U niversidad Autónoma de Puebla, pero no es menos cierto que con el cumplimiento de esas encomiendas se gana el reconocimiento y la gratitud de los poblanos y de todos los mexicanos en general. En el "M ensaje" introductorio con el que abre el libro, el doctor Enrique D oger, rector de esa casa de estudios, expresa su satisfacción y reconoce el privilegio de haber contribuido a dar a las prensas el libro que nos ocupa, declaración que debe tomarse como una prueba de que las autoridades y personal académico de la misma han asumido con seriedad ese compromiso.

\author{
s
$A B C D F$. D iccionario gráfico de la ciudad de M éxico \\ Cristina Faesler Bremer (ed.) \\ M éxico, Editorial D iamantina, 200I, 1504 pp. \\ por \\ PETER KRIEGER
}

$A B C D F$ es un libro que pesa varios kilos, circula en un tiraje de quince mil ejemplares y contiene dos mil imágenes (seleccionadas de un total de veintitrés mil) de la mega-ciudad de M éxico. Aparentemente, la opulencia del libro refleja la mega-dimensión de esta ciudad. Pretende ser, según su editora Cristina Faesler Bremer, un "diccionario gráfico", porque el abundante caos de imágenes se presenta ordenado bajo un esquema alfabético de quinientos veinticinco tópicos. Después de dos años de investigación, Faesler y su equipo pusieron a la disposición del público mexicano un material espléndido para estudiar la fenomenología de la mega-urbe mexicana. Introdujeron un discurso visual que se distingue claramente de otros estudios sobre la ciudad de M éxico, como el catálogo Asamblea de ciudades (1992), coordinado por Alfonso Morales Carrillo, o los ensayos antropológicos y sociológicos acumulados por $\mathrm{N}$ éstor $\mathrm{G}$ arcía $\mathrm{C}$ anclini en Cultura y comunicación en la ciudad de M éxico (1998), entre otros más. Como casi todos los intentos por acercarse a las realidades múltiples, contradictorias y por supuesto estimulantes de la mega-ciudad de M éxico, también este diccionario presenta sólo facetas y fragmentos, sin intentar ni lograr siste- 
DOI: http://dx.doi.org/10.22201/iie.18703062e.2002.81.2130

\section{I84 LIBROS}

matizar el entendimiento del fenómeno "megalópolis" en su condición específica mexicana.

Es notoria la dominación de la imagen frente al texto. En grandes letras, sobre trasfondos de color, los cuarenta y cinco textos de varios autores, de todas las épocas, inte rrumpen la inundación de imágenes. M ientras en muchos casos los autores utilizan - para no decir abusan de - las imágenes para aligerar sus textos secos, ABCDF invierte este principio. Para imprimir una dimensión intelectual al proyecto visual, incluyeron un glosario y algunos fragmentos de textos. Éstos aparecen sin mencionar a los autores, cuyos nombres están escondidos en el apéndice. Tal vez este descuido intencional refleja el anonimato de las personas en la megalópolis, en la cual también un autor de best-sellers de anécdotas urbanas como Carlos M onsiváis se disuelve. El desequilibrio entre texto e imagen, posiblemente, también expresa la estupefacción de una joven generación chilanga de artistas y diseñadores que no es capaz de desarrollar conceptos analíticos para entender su propio ambiente. Lo que cuenta es el empaque gráfico de la fluidez de imágenes; no importa la interpretación de ellas.

Esta condición no se explica por una re gresión colectiva y generacional de la capacidad cerebral, sino simplemente por una moda anacrónica del diseño editorial. Al inicio de los años noventa, Rem Koolhaas y Bruce $M$ au revolucionaron el diseño de libros sobre arquitectura, cultura urbana y life styles, montaron choques gráficos de fotografías manipuladas, estadísticas y frases fiIosóficas, todo acumulado en libros de gran tamaño y enorme peso. Lo que Koolhaas demostró en su autobiografía profesional $\mathrm{S}$, M , L, XL (Rotterdam, 1995) fue copiado posteriormente en M éxico por su ex alumno Fernando Romero en el libro ZM VM (M éxico, 2000), y ahora se repite en $A B C D F$. Las series de fotografías de la entrada "N eza" del diccionario visual (p. 69o), o la yuxtaposición múltiple de "ventanas" (pp. I218-I22I) comprueban que una innovación del diseño producido en Londres y Rotterdam hace una década todavía es vendible como el último grito de la moda en M éxico. Sin embargo, ¿este acto de globalización unidireccional se explica por el miedo de arriesgar verdaderas innovaciones?, ¿0 son las presiones de comercialización lo que hizo a Cristina Faesler y su equipo recurrir a estándares visuales ya ampliamente comprobados a nivel internacional?

Peor aún, la comparación con el omnipresente discurso global de Koolhaas revela debilidades conceptuales de ABCDF. EI show visual de Koolhaas sí está fundado en profundas, inteligentes e incluso cínicas reflexiones sobre la condición de nuestra cultura de las ciudades; pero la lectura de $A B C D F$ se agota en el principio de la acumulación de datos visuales. Es un libro he cho para una generación estéticamente educada por el zapping entre los cientos de canales televisivos, es decir por la fragmentación de la percepción y la reflexión interrupta. Aún más, el saltar entre las dos mil entradas visuales del libro-diccionario está limitado por el cansancio del lector sobreexcitado por las asociaciones infinitas.

Sin duda, la descontextualización libertinaria de imágenes megalopolitanas en $A B C D F$ sorprende y estimula; ipero en qué direcciones se desarrolla el entendimiento del lector? ¿C uál es el potencial epistemológico de las imágenes? El ejemplo del logotipo de la companía estatal "Luz y Fuerza" (p. 596) revela una posible respuesta para- 
digmática. Esta gráfica compuesta por un rayo y dos letras evoca el espíritu de los héroes de ciencia ficción como Flash G ordon 0 Spiderman; de esta manera la compañía demostró su contemporaneidad a nivel de la cultura popular. Fue un producto efectivo y afectivo de autopromoción. Surge, entonces, la pregunta sobre si hoy en día, en que se discute la privatización de la electricidad en M éxico, este rayo todavía cumple con su función de expresar "fuerza" estatal, o nada más queda una reliquia de tiempos pasados, impotente frente a los logotipos de las empresas privadas. En el libro, el logotipo aparece como signo sin historia. Los autores no mencionan el diseñador, ni los contextos histórico y estéticos (p. 1325). Sin explicación, el signo se reduce a un objeto descontextualizado y extraño. Aquí los caminos del entendimiento terminan y el lector cambia la página para ver el siguiente estímulo visual. No quiero reclamar una sobre-explicación, que también puede limitar la lectura de la imagen, pero sí una ayuda epistemológica a través de la información básica.

El caso de "Luz y Fuerza" es característico de la construcción del libro ABCDF y evoca la reflexión sobre las codificaciones sociales, culturales y psicológicas de la lectura de imágenes. ¿H acia dónde llevan los procesos de percepción y evaluación? ¿Estimulan al lector megalopolitano para revisar su propio ambiente vital y, en consecuencia, comprometerse más con ello? ¿0, paraliza la cantidad de imágenes al lector tanto como al televidente frente al bombardeo visual desde la pantalla? Estos cuestionamientos de una sociología de la imagen en la actualidad faltan en ABCDF, y probablemente con cierta razón: porque no sólo es muy chic para la joven generación estadunidizada sustituir el compromiso por coolness, sino también por- que la negación es una actitud común de una sociedad que se debería enfrentar con tan serios problemas sociales y ecológicos como se ven en la ciudad de M éxico. M uchas situaciones características de estos problemas están ausentes en ABCD F, como las predominantes autoconstrucciones en las periferias anchas de la ciudad.

El caos creativo del desarrollo urbano en M éxico sólo aparece en pocas ocasiones, como por ejemplo en la fotografía aérea del mercado informal de Tepito (p. Io66), una estructura de creatividad colectiva hecha sin urbanistas frente a una imposición modernizadora de los años sesenta, el mercado edificado en concreto armado. 0 tro tema de importancia sociocultural para la megalópolis actual, la seguridad, está presente en dos entradas, "cabina" (p. i8o) y "malla" (p. 6oo). Estas fotografías habrían permitido una reflexión seria sobre la erosión de lo público y el aislamiento espacial en la mega-ciudad. Las cabinas de vigilante de calles cerradas y las mallas son ya fenómenos omnipresentes e indicadores de altas tensiones sociales; pero las fotografías presentadas confirman más su cotidianidad y no su función desastrosa para el metabolismo ciudadano. ${ }^{\text {I }}$

Un aspecto muy interesante que surge de la lectura de ABCDF - y también de su exposición en el Palacio de Bellas Artes, entre marzo y junio de 2002- es la transformación de los objetos cotidianos de la ciudad en objetos estéticos autónomos, que además

\footnotetext{
I V éase al respecto Peter K rieger, "D esamores a la ciudad-satélites y enclaves", en XXIII Coloquio Internacional de H istoria del Arte. Amor y desamor en las artes, Arnulfo H errera (ed. ), M éxico, U niversidad $\mathrm{N}$ acional Autónoma de M éxico, Instituto de Investigaciones Estéticas, 200I, pp. 587606.
} 
DOI: http://dx.doi.org/10.22201/iie.18703062e.2002.81.2130

\section{I86 LIBROS}

cuestionan seriamente la existencia de las artes plásticas tradicionales. M ientras una obra de arte actual tiene que luchar con su no comunicabilidad o simplemente con su encarcelamiento en las galerías aisladas, la urbe misma cada día produce una cantidad impresionante de formaciones estéticas. El minimal art de puertas de aluminio (pp. 89o y ss.), el arte povera de parches que tapan una coladera ( $p$. 77i) y el neo-constructivismo de las cajas en la $C$ entral de Abastos (pp. I2-15) son, en mi opinión, las verdaderas vanguardias estéticas en la cultura actual megalopolitana, y no los intentos frustrantes del arte actual de ser "absolutamente moderno". Felicito a los autores de ABCDF por este esfuerzo de romper las fronteras tradicionales entre arte "alto" y "popular", porque todas las articulaciones visuales en el ambiente de la mega-ciudad merecen la atención de la investigación estética. Sólo es una pena que a los doscientos cincuenta artistas que colaboraron en $\mathrm{el}$ proyecto $A B C D F$ no se les ocurriera incluir el fenómeno globalizador e impactante de los graffiti.

Uno de los artistas, Pedro Friedeberg, expone - al estilo de M.C. Escher- en las guardas del libro el motivo que alentó $A B C D F$ : la confusión del laberinto urbano con las letras que intentan sin éxito ordenarIo. Como ya ha demostrado la vanguardia artística de los años veinte, el montaje de choques visuales es la manera adecuada para capturar el caos inentendible de las grandes metrópolis. Así, chocan los motivos, las perspectivas, los enfoques u otras manipulaciones de las fotografías en el libro; como, por ejemplo, la combinación de una vista aé rea del Palacio de los D eportes (p. 738) con una fotografía detallada de una paleta (p. 740), ambas formas redondas. Este salto de escala sí aguza la percepción de la opulencia y riqueza visual que se encuentra en la mega-ciudad de M éxico.

Si hay un resumen de la lectura de $A B C D F$, es la comprensión de que la ciudad misma es la obra de arte más diversa y divertida, interminable y siempre exigente. Sus rupturas visuales, visibles en las entradas "edificio" (pp. 354-355), con los muros desnudos, negando cualquier contextualidad, y "espectacular" (pp. 368-37I), con la contaminación visual, a veces surrealista, de letras y andamios, sirven para un proyecto de educación estética. En la última entrada del diccionario ABCDF, "zoom" (pp. I294-I296, y glosario, p. I36I), los autores utilizan un instrumento óptico para homenajear su objeto de estudio, la ciudad de M éxico. Con la distancia reflexiva de una vista aérea surge el marco que da sentido a todo este megacollage fotográfico llamado ABCDF. Su "asociación libre y lúdica de ideas" (p. 9) merece la atención de muchos lectores con mentalidad abierta. Sería lamentable que $A B C D F$ se limite a fungir como coffee table book de la generación $X$. 